\title{
IMPACT OF FOREIGN AIDS ON POVERTY ALLEVIATION IN NIGERIA \\ ${ }^{1}$ Adebayo, Abiola Georgina; ${ }^{2}$ Afolayan, Olufunmilayo T. \\ ${ }^{1}$ Department of Business Economics, Wageningen University and Research, Netherlands. \\ ${ }^{2}$ General Studies Department, the Federal Polytechnic, Ilaro, Nigeria.
}

*Corresponding Author: Adebayo Abiola Georgina

Corresponding Author Email: georginaabiola@gmail.com

Article Received:03-10-19 Accepted: 30-11-19
Published:05-12-19

Licensing Details: Author retains the right of this article. The article is distributed under the terms of the

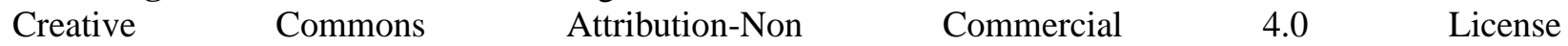
(http://www.creativecommons.org/licences/by-nc/4.0/) which permits non-commercial use, reproduction and distribution of the work without further permission provided the original work is attributed as specified on the Journal open access page.

\begin{abstract}
The aim of the study is to examine the impact of foreign aid on poverty alleviation in Nigeria over the period of 1990 to 2017. Data were collected from UNCTAD World Bank database and CBN Statistical Bulletin. Consequently, Cointegration, DOLS and Granger Causality techniques were utilized to address the objective of the study. The major findings are summarized as follow: Foreign aid has not led to poverty alleviation in Nigeria. Similarly, FDI has a negative impact on household consumption per capita and not significant at $10 \%$ level of significance. This implies that FDI does not reduce poverty in Nigeria. In addition, there is an existence of insignificant positive relationship between inflation rate and household consumption per capita in Nigeria. Furthermore, there is a unidirectional causality which runs from foreign aid to household consumption per capita. However, there is no feedback relationship between foreign aid and FDI, likewise FDI and household consumption per capita. Also, there is a unidirectional causal relationship flowing from inflation rate to household consumption per capita. Finally, due to the findings it is recommended that since foreign aid has no reducing impact on poverty in Nigeria, the policy makers should not depend on foreign aid as the only means of combating poverty in Nigeria. Therefore, a holistic approach for tackling the challenge of poverty in Nigeria is suggested and should be embraced.
\end{abstract}

Keywords: Foreign Aids; Poverty Alleviation; FDI; Nigeria 


\section{INTRODUCTION}

High level of poverty is a critical challenge confronting developing economies generally. That is why Millennium Development Goals (MDGs) document was geared towards eradication of poverty and hunger in these economies by 2015. However, after the appraisal of success of MDGs in 2015 it was discovered that despite the fact that MDGs have been achieved at the global level, some countries are still lagging behind with high degree of poverty thus leading to the emergence of sustainable development goals (SDGs).

Nigeria as perceived is one of the countries in Africa characterized by a high level of poverty in the twenty first century. According to the World Poverty Clock report in 2018, Nigeria has estimated 86.9 million people living in extreme poverty. This number is the highest in the globe. In view of the above, several advocacies have been put forward for the adoption of a holistic approach to tackle poverty in the country. One of the viable approaches that could address poverty is the usage of foreign aids. In the past few decades African countries have been largely dependent on foreign aids for developmental projects. Going by memory lane for the past 30 years, developing countries of Africa have been the most popular beneficiaries of foreign aids in the world with estimated $40 \%$ of the global foreign aids; followed by South and Central Asian countries which accounted for $20.7 \%$ (OECD, 2016).

However, the following statistics show that ECOWAS countries have attracted a significant proportion of foreign aids over time. From 1980 to 1990, the ECOWAS sub region received 26\% of total aids in Africa. It reduced to $25 \%$ from 1991 to 2000 which later rose to $28 \%$ from 2001 to 2015 respectively. Nigeria as a dominant country in ECOWAS sub region has attracted a substantial amount of foreign aids. It is worth of note that foreign aids fluctuated in Nigeria from $\$ 118.1$ million in 1988 to $\$ 2.1$ billion in 2010. But, in 2005 and 2006, foreign aids rose astronomically from $\$ 6.4$ billion and $\$ 11.4$ billion which is the highest in the history of Nigeria (OECD, 2016: WDI, 2016). The rise in this figure is probably due to forgiveness of the country`s debt by the Paris Club of creditors.

Foreign aids could be a weapon to fight poverty in developing countries through financing of developmental projects that have trickle down effects on the masses. Meanwhile, when it comes to Nigeria, there have been different opinions regarding the impact of foreign aids on poverty alleviation in the country. It has been argued that Nigeria does not need foreign aids to fight poverty because of huge revenues which the country obtains from crude oil and large bulk of remittances from its citizens working overseas. In the recent time, an attempt to empirically examine the impact of foreign aids on poverty alleviation in Nigeria has generated a lot of arguments and conflicting results in the literature. For instance, JideIbietan, Felix and Ese (2014) submitted that foreign aid did not bring about poverty alleviation in Nigeria. Contrarily, Akpan and Udoma (2010) discovered an insignificant positive impact of foreign aids on economic development in the country. Similarly, N"edri Kan (2017) concluded that foreign aids led to poverty reduction among ECOWAS countries. Due to inconclusiveness of the literature regarding foreign aids and poverty alleviation nexus in Nigeria makes the study imperative in this time. Therefore, 
this study examined the impact of foreign aids on poverty alleviation in Nigeria between 1990 and 2017. The scope of the study is long enough to assess the trickle-down effects of foreign aids on people's welfare and standard of living in the country.

\section{LITERATURE REVIEW}

This section shows the review of past studies regarding the subject matter in developing countries generally and Nigeria in particular. Bharadwaj (2014) utilizes a panel regression analysis to estimate the link between globalization and poverty in 35 developing countries from 1990 to 2004. The paper opines that globalization leads to reduction of poverty in the selected countries. Arnt et al. (2011) adopts the LIML point estimates to show that a sustained inflow of 25 USD aid per capita is supposed to increase growth rate, alleviate poverty, gear up investments, increase average schooling, increase life expectancy and bring about a decline in infant mortality. In another related study, Needri Kan (2017) estimates the relationship between official development assistance and poverty alleviation in developing countries of ECOWAS using a panel data analysis from 1980 to 2014. The findings from the study show that ODA contributes to poverty reduction in ECOWAS sub region. But it brings about inimical effect on economic growth. As such the author concludes that ODA is pro-poor and not facilitating growth in ECOWAS sub region. In the same vein, Askarov (2015) adopts technique of instrumental variables to posit that aids and economic growth have positive relationship with each other in emerging countries. Akpan and Udoma (2010) apply least squares (3SLS) estimation technique to estimate the nexus between ODA and economic performance in Nigeria from 1970 to 2010. The study discovers a positive but insignificant relationship between ODA and economic development in the country. Meanwhile, the relationship between capital expenditure and economic development is significant.

Moreover, Mahmood and Chaudhary (2012) investigated the relationship between FDI and poverty reduction in Pakistan from 1973 to 2003 by employing Autoregressive Distributed Lag (ARDL) model. The study emphasizes that FDI brings about poverty reduction in the country. EskanderAlvi (2008) assesses the linkage between aid and the importance of policy framework in generating economic growth in developing countries. The author submits that policy constitutes a crucial factor in determining economic growth, and as such economic growth emanates from aids in an environment that is constituted with good policies; despite this fact an evidence to support diminishing returns to aid exists. Ucal (2014) evaluates how FDI spillover affects poverty level in 26 developing countries using unbalanced panel analysis from 1990 to 2009. The author argues that FDI has a negative relationship with poverty in the selected countries. JideIbietan, Felix and Ese (2014) state that in spite of huge flows of ODA to Nigeria on an annual basis, poverty level has not yet reduced in the country.

In addition, it could be concluded from the above reviewed literature that past studies on the relationship between foreign aids and poverty alleviation in Nigeria are very scanty in the recent times. Hence, the relevance of this study. 


\section{An Overview of Poverty Level in Nigeria}

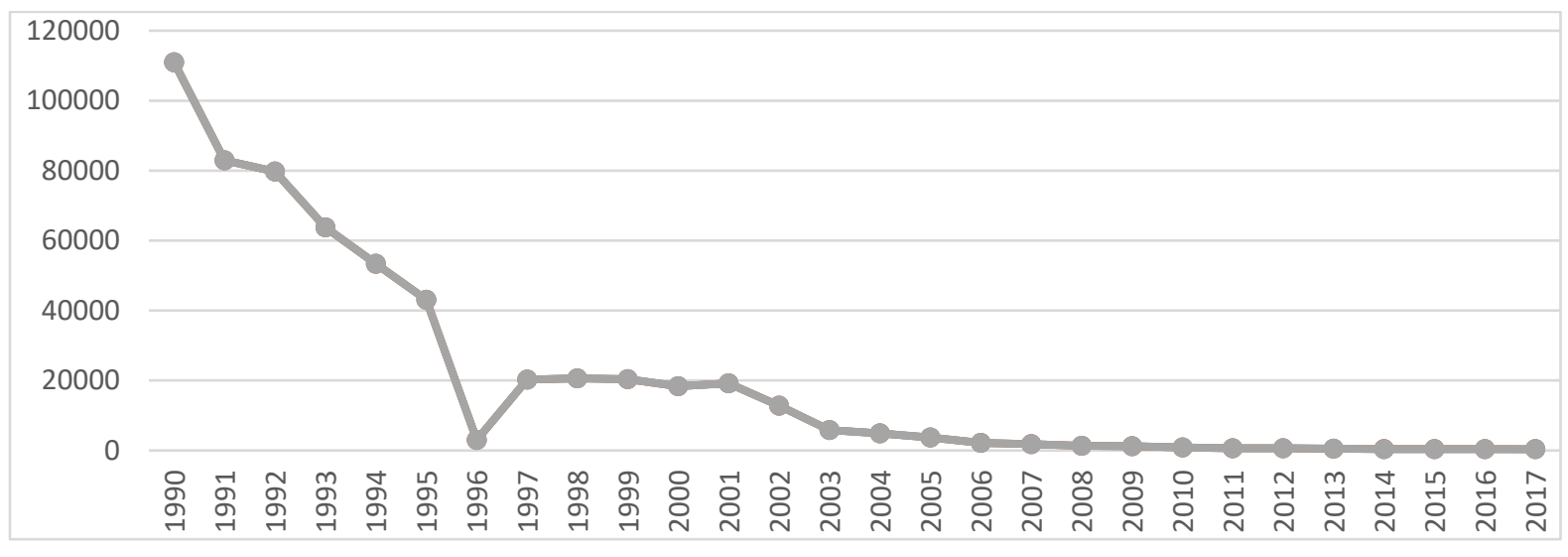

Figure 1: Household Consumption Per Capita in Nigeria

Source: Authors' Computation (2019) from (CBN, 2017)

In Figure 1, the household consumption per capita in Nigeria was presented. This measures the standards of living of individuals in the country from 1990 to 2017. As shown in the figure, the living standards of individuals in Nigeria diminished from 1990 to 1996 after which it rose in 1997. However, the standard of living continued to diminish from 1998 to 2017. This shows that the level of poverty has been on the increase in Nigeria from 1990 to 2017. In other words, the welfare of citizens in Nigeria is decreasing on daily basis due to the continuous rise in the level of poverty

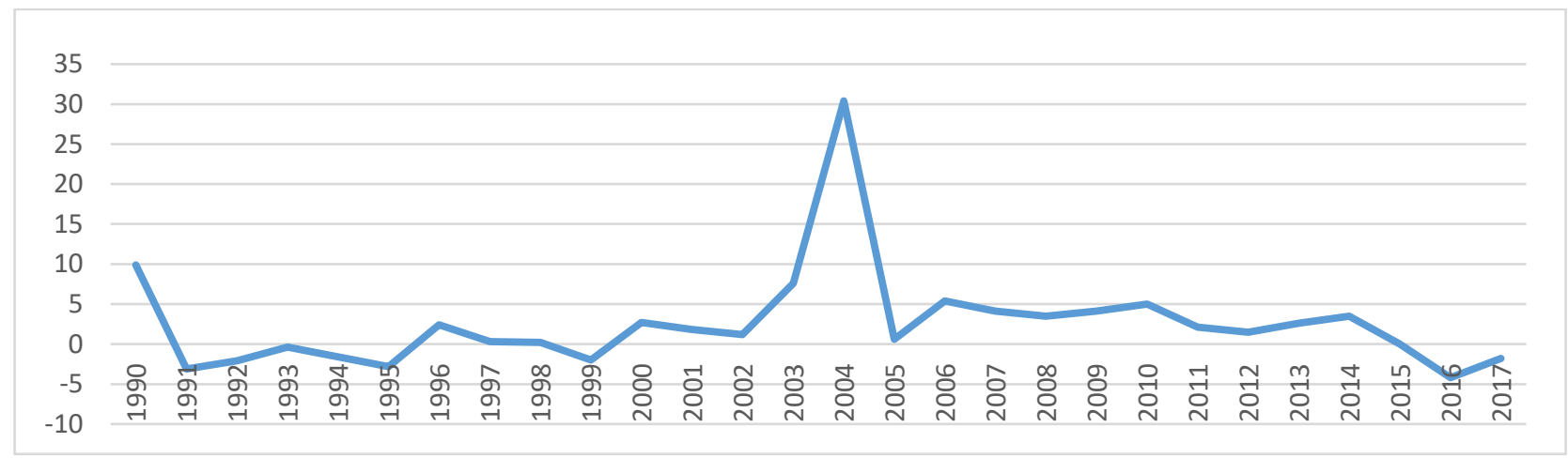

Figure 2: GDP Per Capita Growth in Nigeria

\section{Source: Authors' Computation (2019) from (WDI, 2018)}

GDP per capita growth is another variable that measures the standard of living in an economy. The figure 2 shows fluctuations in the performance of this variable from 1990 to 2017 in Nigeria. To be explicit, from 1990 to 1991 GDP per capita growth declined sharply. From 1991 to 1999, GDP per capita growth has been fluctuating until 2000 when there was a rise in this variable. It is worthy of note that GDP per capita growth reached its peak in 2004 before there was a sharp decline in 2005. The variable fluctuated between 2006 and 2017. This shows that the performance of GDP 
per growth has not been impressive in Nigeria except 2004 and 2005 when the country enjoyed forgiveness debt by the Paris Club of creditors in year 2005. Also, in 2016 and 2017 GDP per capita growth was negative which shows evidence of spillovers of recession experienced in the country late 2015.

In conclusion, both household consumption per capita and GDP per capita growth data show that on the aggregate, poverty level has been on the increase continuously in Nigeria, this will invariably cause a continuous dwindling of standards of living of the people in the country.

\section{METHODOLOGY}

This paper makes use of secondary data between 1990 and 2017. Foreign aid data were extracted from World Development Indicator. FDI data were sourced from UNCTAD investment report, data on household consumption per capita and inflation rate were from the Central Bank of Nigeria Statistical Bulletin.

\section{Model Specification}

$\mathrm{HCP}=\mathrm{F}(\mathrm{FA}, \mathrm{FDI}, \mathrm{Inf})$

If the above model is linearized, it generates model (II)

$\mathrm{LnHCPt}=\beta_{1}+\beta_{2} \operatorname{LnFAt}+\beta_{3} \operatorname{LnFDIt}+\beta_{4} \operatorname{Inft}+\mu$

Where;

HCP represents household consumption per capita which measures the standard of living of the people.

FA is used to proxy the inflows of foreign aids into Nigeria

FDI is foreign direct investment inflow.

Inf is inflation rate

$\beta 1=$ Intercept, $\beta 2-\beta 4=$ coefficients of independent variables, $\mu \mathrm{i}=$ Stochastic or error term and $\mathrm{t}$ = 1990-2017.

The a priori expectations are as follows $\beta 2$ and $\beta 3>0, \beta_{4}<0$.

\section{The Direction of Causality between FA, FDI, HCP and Inf. in Nigeria.}

The model for Granger causality between poverty and official development assistance could be examined within a pairwise granger causality analysis with the estimation of the VAR model in equation (III-VI) which states thus:

$F A_{t}=\alpha_{0}+\sum_{i=0}^{p} \alpha_{1} F A_{t-1}+\sum_{i=0}^{p} \alpha_{2} F D I_{t-1}+\sum_{i=0}^{p} \alpha_{3} H C P_{t-1}+\sum_{i=0}^{p} \alpha_{3} I n f l_{t-1}+\varepsilon_{1 t^{-----}}$ (III) 
$F D I_{t}=+\beta_{0}+\sum_{i=0}^{p} \beta_{1} F D I_{t-1}+\sum_{i=0}^{p} \beta_{2} F A_{t-1}+\sum_{i=0}^{p} \beta_{3} \operatorname{Infl}_{t-1}+\sum_{i=0}^{p} \alpha_{3} H C P_{t-1}+\varepsilon_{2 t^{--}}$ (IV)

$H C P_{t}=\gamma_{0}+\sum_{i=0}^{p} \gamma_{1} H C P_{t-1}+\sum_{i=0}^{p} \gamma_{2} F A_{t-1}+\sum_{i=0}^{p} \gamma_{3} I n f l_{t-1}++\sum_{i=0}^{p} \alpha_{3} F D I_{t-1} \varepsilon_{4 t^{--------}}$ (V)

Infl $_{t}=\gamma_{0}+\sum_{i=0}^{p} \gamma_{1} \operatorname{Infl} l_{t-1}+\sum_{i=0}^{p} \gamma_{2} F D I_{t-1}+\sum_{i=0}^{p} \gamma_{3} F A_{t-1}+\sum_{i=0}^{p} \alpha_{3} H C P_{t-1}+\varepsilon_{4 t^{-------}}$ (VI)

\section{Measurement of Variables}

The variables of interest in this study are defined operationally as follow:

FDI: This measures the total foreign direct investment in all sectors of the Nigerian economy.

HCP: This is household consumption per capita in Nigeria and is used to measure the level of poverty in the country.

FA: This is foreign aids and is measured by foreign development aids in terms of disbursements of loans made on concessional terms (net of repayments of principal) and grants by official agencies to Nigeria.

Infl: This is inflation rate and it measures the general price level in the country.

\section{Techniques of Analysis}

This section illustrates the approaches that would be employed to achieve the various objectives of this work. Descriptive analysis is used to compliment econometric analysis in examining the impact of aids on poverty alleviation in Nigeria.

\section{RESULTS AND DISCUSSION}

Table 1

Descriptive Statistics of Annual Data Series (1990-2017)

\begin{tabular}{lcccc}
\hline Descriptive Statistics & Infl & LFDI & FA & LHCP \\
\hline Mean & 18.71679 & 21.74894 & 20.55825 & 8.510400 \\
Median & 12.55000 & 21.52907 & 21.09918 & 8.359423 \\
Maximum & 72.84000 & 22.91100 & 23.15968 & 11.61676 \\
Minimum & 5.380000 & 20.72626 & 18.83933 & 5.881426 \\
Std. Deviation & 17.42350 & 0.726565 & 1.268096 & 1.936870 \\
Skewness & 1.958346 & 0.160137 & 0.130368 & 0.101213 \\
Kurtosis & 5.646040 & 1.593786 & 1.734688 & 1.587534 \\
Jarque-Bera & 26.06566 & 2.426683 & 1.947164 & 2.375374 \\
Probability & 0.000002 & 0.297203 & 0.377728 & 0.304926 \\
Sum & 524.0700 & 608.9704 & 575.6310 & 238.2912 \\
Sum. Sq. Deviation & 8196.619 & 14.25320 & 43.41781 & 101.2896 \\
& & & & \\
Observation & 28 & 28 & 28 & 28 \\
\hline
\end{tabular}

Source: Authors' Computation (2019) 
The assumptions of normality and asymptotic properties of data series are very important when carrying out econometric analyses. As a result of this, an attempt has been made to examine various descriptive statistics of the data utilized for this work. From Table 1 above, the values of mean and median of the following variables FDI, foreign aid, and household consumption per capita are very close, apart from that of inflation rate which shows a slight difference. This shows that the data are normally distributed. Also, the value of kurtosis of the data series of FDI, foreign aid and household consumption per capita are very close to 3 . This implies that the data series are fairly distributed.

Table 2

Unit Root Test

\begin{tabular}{lllllll}
\hline \multirow{2}{*}{ Variables } & ADF Test & \multicolumn{5}{l}{ PP Test } \\
\cline { 2 - 7 } & Level & $1^{\text {st }}$ Diff. & Remarks & Level & $1^{\text {st }}$ Diff. & Remarks \\
\hline LFA & $-2.976263^{* *}$ & $-2.981038^{* *}$ & I $(1)$ & $-2.976263^{* *}$ & $-2.981038^{* *}$ & I (1) \\
LFDI & $-2.976263^{* *}$ & $-2.981038^{* *}$ & I $(1)$ & $-2.976263^{* *}$ & $-2.981038^{* *}$ & I $(1)$ \\
Inf & $-2.976263^{* *}$ & $-2.981038^{* *}$ & I $(1)$ & $-2.976263^{* *}$ & $-2.976263^{* *}$ & I $(1)$ \\
HCP & $-2.981038^{* *}$ & $-2.981038^{* *}$ & I $(1)$ & $-2.976263^{* *}$ & $-2.981038^{* *}$ & I (1) \\
\hline Source; Authors Computation (2019) & & & $* *$ & $*$ & \% 5 level
\end{tabular}

Table 2 shows the results of unit root test using the standard Augmented Dickey-Fuller (ADF) and Phillips-Perron (PP) tests. Unit root test is very important because time series data usually have a stationarity problem which could reduce the validity of the policy recommendations based on research outcomes from using such data. Consequently, the results of the estimated Augmented Dickey-Fuller (ADF) and Phillips-Perron (PP) tests show that data for all the variables were not stationary in their native form but became stationary after first differencing. This implies that the data possess a unit root at their levels.

Table 3

Johansen Cointegration Test (Trace Statistics) and (Maximum Eigenvalue)

\begin{tabular}{lllccc}
\hline Null Hypothesis & Eigenvalue & Trace Statistics & P-value & Maximum Eigenvalue & P-value \\
\hline $\mathrm{r}=0$ & 0.571750 & 37.77096 & 0.3121 & 22.04925 & 0.2178 \\
$\mathrm{r} \leq 1$ & 0.380282 & 15.72171 & 0.7317 & 12.44075 & 0.5048 \\
$\mathrm{r} \leq 2$ & 0.100541 & 3.280961 & 0.9527 & 2.754996 & 0.9617 \\
$\mathrm{r} \leq 3$ & 0.020026 & 0.525966 & 0.4683 & 0.525966 & 0.4683 \\
\hline
\end{tabular}

Source; Authors`Computation (2019)

The unit root tests in the previous table show that the variables of interest in this study are stationary at first differencing. This implies that these variables could show deviation in the short run but there is high possibility they have a long run convergence. Therefore, this study employed Johansen and Juselius (1990) multivariate cointegration test to verify the existence or otherwise of the long run equilibrium relationship among the variables. The results shown in Table 3 indicate that there is an existence of at most three cointegrating vectors in the systems from the eigenvalue and the maximal eigenvalue statistics. This implies that these variables have a long run equilibrium relationship hence, there will be convergence in the long run. 
Table 4

The Impact of Foreign Aids on Poverty Alleviation in Nigeria

Dependent Variable: LHCP

\begin{tabular}{llll}
\hline \multicolumn{1}{c}{ Variable } & Coefficient & t-statistics & P-value \\
\hline LFA & $-0.854340 * *$ & 1.806398 & 0.0960 \\
LFDI & -0.751942 & 1.057302 & 0.3112 \\
Infl & 0.027271 & 1.674066 & 0.1200 \\
C & $41.69552 *$ & 5.208206 & 0.0002 \\
R-Squared & 0.928657 & & \\
Adjusted R-Squared & 0.857315 & & \\
Source; CBN, 2017: Authors`Computation (2019) \\
\multicolumn{4}{r}{$* *$ Significant at 10\%, *Significant at 1\%, }
\end{tabular}

Table 4 shows the estimated results of the regression analysis of the nexus between foreign aids and poverty alleviation in Nigeria. All the explanatory variables did not have expected signs. The independent variables of the model which comprises foreign aids, FDI and inflation rate jointly explained about $92 \%$ of the systematic variations in the dependent variable, household consumption per capita, leaving $8 \%$ unexplained owing to random chance. Therefore, the model adopted for this study is relatively good. Meanwhile, the explanatory power reduces to about $86 \%$ when the degree of freedom was adjusted.

Consequently, foreign aid has a negative impact on household consumption per capita, which is significant at $10 \%$ level of significance. A unit change in foreign aids leads to the reduction in household consumption per capita by $85 \%$. This implies that foreign aid has not led to poverty alleviation in Nigeria. This study is in line with the findings of JideIbietan, Felix and Ese (2014)

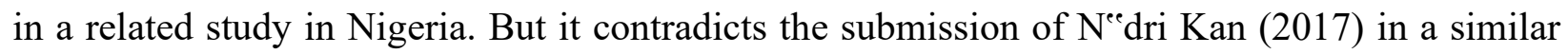
study in ECOWAS countries.

Similarly, FDI has a negative impact on household consumption per capita but not significant at $10 \%$ level of significance. This implies that FDI does not reduce poverty in Nigeria. This finding corroborates the assertion of Ogunniyi and Igberi (2014) as well as that of Akinmulegun (2012) who carried out similar studies in Nigeria. In addition, there is an existence of an insignificant positive relationship between inflation rate and household consumption per capita in Nigeria.

Table 5

Pairwise Granger Causality Test

\begin{tabular}{lccc}
\hline Sample: 19902017 & & & \\
Lags: 2 & & & \\
\hline & Obs & F-Statistic & Prob. \\
Null Hypothesis: & 26 & 2.29332 & 0.1257 \\
\hline & & 1.83952 & 0.1836 \\
LFA does not Granger Cause LFDI & & & \\
LFDI does not Granger Cause LFA & 26 & 0.12399 & 0.8840 \\
\hline
\end{tabular}




\begin{tabular}{lccc}
\hline LFDI does not Granger Cause LHCP & & 2.17256 & 0.1388 \\
& 26 & 2.12417 & 0.1445 \\
INFL does not Granger Cause LFDI & & 1.54755 & 0.2361 \\
LFDI does not Granger Cause INFL & 26 & 2.17691 & 0.1383 \\
& & 3.73437 & 0.0410 \\
LHCP does not Granger Cause LFA & 26 & 0.74415 & 0.4873 \\
LFA does not Granger Cause LHCP & & 3.23816 & 0.0595 \\
& & & \\
INFL does not Granger Cause LFA & 26 & 6.75923 & 0.0054 \\
LFA does not Granger Cause INFL & & 1.89867 & 0.1746 \\
& & & \\
INFL does not Granger Cause LHCP & & &
\end{tabular}

\section{Source; Authors`Computation (2019)}

This section examined the relationship between household consumption per capita, FDI, foreign aids and inflation rate in Nigeria within the context of Pairwise Granger Causality Test. The estimated results show that there is a unidirectional causality which runs from foreign aid to household consumption per capita. This implies that foreign aid granger causes poverty level in the country. However, there is no feedback relationship between foreign aid and FDI, likewise FDI and household consumption per capita. There is a unidirectional causal relationship flowing from inflation rate to household consumption per capita.

\section{CONCLUSION AND RECOMMENDATIONS}

This study examines the connection between foreign aids and poverty alleviation in Nigeria over the period of 1990 to 2017. The following are the major findings in the study: Foreign aid has a negative impact on household consumption per capita. This implies that foreign aid has not led to poverty alleviation in Nigeria. Similarly, FDI has a negative impact on household consumption per capita but not significant at $10 \%$ level of significance. This implies that FDI does not reduce poverty in Nigeria. In addition, there is an existence of an insignificant positive relationship between inflation rate and household consumption per capita in Nigeria. Furthermore, there is a unidirectional causality which runs from foreign aid to household consumption per capita. However, there is no feedback relationship between foreign aid and FDI, likewise FDI and household consumption per capita. Also, a unidirectional causal relationship flowing from inflation rate to household consumption per capita is observed.

Finally, due to the findings that emerged in this study, the following recommendations can be made since foreign aid did not lead to poverty alleviation in Nigeria; the policy makers should not depend on foreign aid as the only means of combating poverty in Nigeria. Therefore, all hands must be on the deck to use a holistic approach to tackle poverty in the country.

\section{References}

Akinmulegun, S.O. (2012). Foreign direct investment and standard of living in Nigeria. Journal of Applied Finance and Banking, 2(3), 21-32. 
Akpan, H. E.,\&Udoma, J. A. (2010). Official Development Assistance and Economic Performance in Nigeria, 1970-2010. Journal of Monetary and Economic Integration, 12(1), 125150.

Arndt, C., Jones, S., \&Tarp, F. (2011). Aid, growth, and development: have we come full circle? Journal of Globalization and Development, 1(2), 15-27

Askarov (2015). Development Aid and Growth in Transition Countries. World Development, 66, 383-399.

Bharadwaj, A. (2014). Reviving the Globalization and Poverty Debate: Effects of Real and Financial Integration on the Developing World. Advances in Economics and Business, 2.

CBN. (2017).Statistical BulletinCentral Bank of Nigeria

Dickey, D. A. \& Fuller, W. A. (1981). Likelihood Ratio Tests for Autoregressive Time Series with a Unit Root. Econometrica, 49, 1057 - 1072.

Eskander, A. D. (2008). Aid, Policies, and Growth in Developing Countries A New Look at the Empirics. Southern Economic Journal, 74(3), 693-706

Jide, I., Felix, C.,\& Ese, U. (2014). Poverty Alleviation and the Efficacy of Development Assistance Models in Nigeria: An Appraisal.International Journal of Humanities Social Sciences and Education (IJHSSE), 1(5), 1-8.

Johansen, S. \& K. Juselius (1990). Maximum Likelihood Estimation and Inference on Cointegration with Applications to Demand for Money.Oxford Bulletin ofEconomics and Statistics 52, PP. 169-210.

Mahmood, H. and Chaudhary, A.R. (2012). A Contribution of Foreign Direct Investment in Poverty Reduction in Pakistan.Middle East Journal of Scientific Research. 12(2), 89-97.

Nadri, K.D. (2017). Contribution of Official Development Assistance to Poverty Alleviation in the Ecowas, IOSR Journal of Economics and Finance (IOSR-JEF), 8(2), 37-49

OECD. (2016). www.oecd.org/development/financing-sustainable-development/final-ODA.htm

Ogunniyi, M.B.,\&Igberi, C.O. (2014).The impact of foreign direct investment on poverty reduction in Nigeria.Journal of Economics and Sustainable Development, 5(14), 12-25.

Okon, E. (2012). Five Decades of Development Aid to Nigeria: The Impact on Human Development.Journal of Economics and Sustainable Development, 3(1), 32- 42.

Phillips, P. C.,\&Perron, P. (1988). Testing for a unit root in time series regression. Biometrika, 75, 335-346

Ucal, M.S. (2014). Panel DataAnalysis Of Foreign Direct Investment and Poverty from the Perspective of Developing Countries.Social and Behavioral Science, 109, 1101 - 1105.

UNCTAD. (2018). World investment Report 2018 published by the United Nations on Trade and Investment. available at ww.unctad.org DATA\%20on\%20FDI\%20BRICS\%201.htm. 6.8.2018.

World Bank. (2018). World Development Indicators. Washington D.C. 